Bangladesh J. Bot. 43(2): 191-196, 2014 (September)

\title{
EFFECTS OF SALT STRESS ON LIPID PEROXIDATION AND ANTIOXIDATIVE ENZYMES OF ALFALFA (MEDICAGO SATIVA L.) CULTIVARS
}

\author{
Ensieh Ashrafi, Morteza Zahedi ${ }^{*}$ and Jamshid Razmjoo \\ Department of Agronomy and Plant Breeding, College of Agriculture, \\ Isfahan University of Technology, Isfahan, Iran
}

Key words: Antioxidative enzymes, Lipid peroxidation, Medicago sativa, Salt stress

\begin{abstract}
The effect of salt stress on enzyme activities of nine alfalfa cultivars at germination and seedling stage was studied. The activities of SOD, GR, POX and APOX were higher in salt tolerant and lower in salt sensitive cultivars. Results of the effect of salt stress on the SOD, GR, POX, APOX activities and MDA content may be used to select salt tolerance cultivars at the germination and seedling stages. SOD, GR, POX, APOX and MDA may play an important role in salt tolerant mechanisms in alfalfa.
\end{abstract}

\section{Introduction}

Alfalfa (Medicago sativa L.) is moderately tolerant to salinity (Howieson and Ballard 2004) but there is high variation between and within cultivars of alfalfa relative to center of diversity (Howieson and Ballard 2004). Therefore, selection of more salt tolerant cultivar at these stages is possible for production of this crop. In addition information on mechanism tolerance of these cultivars at this stage under salt stress is important for selection or screening of salt tolerance cultivars at this stage.

Torabi et al. (2011) reported that the cultivars Nik-Shahri, Rehnani and Gharegozloo were more salt tolerance at germination stage. Reports on the mechanism of salt tolerance in alfalfa cultivars at germination stage are none.

Salt stress can stimulate formation of active oxygen species (AOS) such as superoxide, hydrogen peroxide and hydroxyl radicals. These activated oxygens injure the cellular components of proteins, membrane lipids and nucleic acids (Sudhakar et al. 2001). Malondialdehyde (MDA) is the decomposition product of polyunsaturated fatty acids of membranes and shows greater accumulation under salt stress (Sudhakar et al. 2001). Plants that produce high levels of antioxidants are able to provide better resistance to damage induced by salinity (Bor et al. 2003).

The objective of this study was to evaluate the effect of salt stress on antioxidant enzymes activities in nine alfalfa cultivars to elucidate the possible physiological mechanism of the stress during germination and seedling stages of alfalfa.

\section{Materials and Methods}

Seeds of alfalfa were provided by Agricultural Research Center of Isfahan. Early seedling growth of nine alfalfa (Medicago sativa L.) cultivars (Tolerant cultivars: Rehnani, Esfahani and Gharehyonje. Moderate cultivars: Ranjer, Hamedani and Yazdi. Sensitive cultivars: Nikshahri, Pioneer and Bami) was studied using distilled water and three salinity solutions. Three replicates of 100 seeds of each cultivar were placed between double layered rolled anchor germination papers with $10 \mathrm{ml}$ of relevant experiment solutions. The papers were replaced every 2 days in

*Author for correspondence: <mzahedi@cc.iut.ac.ir>. 
order to avoid salt accumulation. Seeds were allowed to germinate in a growth chamber at $25 \pm 1^{\circ} \mathrm{C}$ in the 16/8 dark and light for 7 days. For dry weight determination, samples were oven dried at 75 $80^{\circ} \mathrm{C}$ for $48 \mathrm{hrs}$.

Lipid peroxidation was determined by estimating the malondialdehyde (MDA) content in the seedling tissues according to Madhava Rao and Sresty (2000).

Fresh samples of seedling tissue first ground with mortar and pestle with liquid nitrogen. $0.5 \mathrm{~g}$ of each powdered sample was then homogenized in ice-cold $50 \mathrm{mM}$ sodium phosphate extraction buffer (pH 6.8) containing $1 \mathrm{mM} \mathrm{Na}_{2}$-EDTA and $2 \%(\mathrm{~W} / \mathrm{V})$ PVPP. The entire extraction procedure was carried out at $4^{\circ} \mathrm{C}$. The homogenate was centrifuged at $13,000 \times g$ for 40 min at $4{ }^{\circ} \mathrm{C}$ and the supernatant was used to assay the activity of superoxide dismutase (SOD), Peroxidase (POX), ascorbate peroxidase (APOX), and glutathione reductase (GR). The enzymatic activity of SOD was determined in terms of its ability to inhibit photochemical reduction of nitrob-blue tetrazolium (NBT) at $560 \mathrm{~nm}$ (Beauchamp and Fridovich 1971). The activity of POX was determined in 3,3' diaminobenzidine-tetrahydrochloride dihydrate (DAB) solution containing $50 \%(\mathrm{~W} / \mathrm{V})$ gelatin and $0.15 \mathrm{M}$ Na-phosphate-citrate buffer $(\mathrm{pH} 4.4)$ and $0.6 \% \mathrm{H}_{2} \mathrm{O}_{2}$ (Herzog and Fahimi 1973). The activity of APOX was assayed as the decrease in absorbance at $290 \mathrm{~nm}$ following the $\mathrm{H}_{2} \mathrm{O}_{2}{ }^{-}$ mediated oxidation of ascorbate (Nakano and Asada 1981). The activity of GR was measured according to Foyer and Halliwell (1976).

The laboratory tests were a two-way factorial $(4 \times 9)$ arranged in a completely randomized design with three replications. Data were subjected to analysis of variance (ANOVA) using GLM procedure of SAS statistical program (ver.9.1) and MSTAT-C procedures. Treatment means were separated using the least significant difference (LSD) test $(P<0.05)$.

\section{Results and Discussion}

The shoot and root lengths and shoot and root dry weights in all cultivars had decreased as salinity level increased (Table 1). The highest decrease in root and shoot length under all salinity levels was in cultivars Esfahani and Rehnani (Table 1). The average reductions in shoot dry weight at saline treatments from $17-19 \%$ in Rehnani, Esfahani and Gharehyonje were distinctly lower than those of other cultivars, and 30 - 57\% in Hamedani, Ranjer, Yazdi, Bami, Nikshahre, and Pioneer (Table 1). In this study, based on root and shoot lengths and weights, Rehnani and Esfahani were the most salt tolerant and Pioneer and Bami were the least tolerant among the tested cultivars. These results are in line with the results reported by Torabi et al. (2011) and Peel et al. (2004). Thus, the cause of the reduction of shoot and root growth was due to salinity induced ionic imbalance (Howieson and Ballard 2004, Jaleel et al. 2008).

Salinity caused 3.05-, 2.21- and 2.13-folds increase in SOD in Rehnani, Gharehyonje, and Esfahani than those of other cultivars. Similarly, increase in SOD by 1.75 - 1.32-folds in Bami, Pioneer, Yazdi, Nikshahre, Hamedani, and Ranjer. Among cultivars, Rehnani had the highest SOD at $180 \mathrm{mM}$ of $\mathrm{NaCl}$ treatment (Table 2). Higher SOD activity in salt-tolerant cultivars of alfalfa was also reported (Wang et al. 2009, Wang and Han 2009).

Salinity $(60-180 \mathrm{mM})$ increase the activity of POX, by 3.77 folds in Ranjer, followed by 2.68-, 2.22-, 2.19-, 1.81-, 1.58-, 1.43-, 1.41- and 1.38-folds in Hamedani, Nikshahre, Yazdi, Rehnani, Pioneer, Bami, Gharehyonje, and Esfahani, respectively (Table 2).

Salinity (6- - $180 \mathrm{mM}$ ) increase the activity of APOX, by 4.39 - 2.23-folds in Pioneer, Bami, Yazdi, Nikshahre, Gharehyonje, Rehnani, Ranjer, Hamedani, and Esfahani (Table 2). 
Table 1. Effect of salinity on the growth parameter of alfalfa cultivars.

\begin{tabular}{|c|c|c|c|c|c|}
\hline Cultivar & $\begin{array}{l}\mathrm{NaCl} \\
(\mathrm{mM})\end{array}$ & $\begin{array}{l}\text { Root length } \\
\text { (cm) }\end{array}$ & $\begin{array}{l}\text { Shoot length } \\
(\mathrm{cm})\end{array}$ & $\begin{array}{l}\text { Root dry weight } \\
\text { (mg) }\end{array}$ & $\begin{array}{c}\text { Shoot dry weight } \\
(\mathrm{mg})\end{array}$ \\
\hline \multirow[t]{4}{*}{ Rehnani } & 0 & $10.1^{c \dagger}$ & $14.2^{\mathrm{b}^{\dagger}}$ & $10.0^{\mathrm{a} \dagger}$ & $144^{\mathrm{a} \dagger}$ \\
\hline & 60 & $9.5^{\mathrm{e}}$ & $13.4^{\mathrm{c}}$ & $9.2^{\mathrm{b}}$ & $134^{\mathrm{b}}(-6)$ \\
\hline & 120 & $8.9^{\mathrm{g}}$ & $12.7^{\mathrm{d}}$ & $8.0^{\mathrm{c}}$ & $124^{\mathrm{cd}}(-13)$ \\
\hline & 180 & $8.6^{\mathrm{hi}}$ & $11.7^{\mathrm{e}}$ & $6.4^{\mathrm{e}}$ & $99^{f}(-31)$ \\
\hline \multirow[t]{4}{*}{ Esfahani } & 0 & $11^{\mathrm{a}}$ & $15.1^{\mathrm{a}}$ & $9.0^{\mathrm{b}}$ & $129^{\mathrm{bc}}$ \\
\hline & 60 & $10.5^{\mathrm{b}}$ & $14.5^{\mathrm{b}}$ & $7.4^{\mathrm{d}}$ & $119^{\mathrm{d}}(-7)$ \\
\hline & 120 & $9.8^{\mathrm{d}}$ & $13.6^{\mathrm{c}}$ & $6.4^{\mathrm{e}}$ & $109^{\mathrm{e}}(-15)$ \\
\hline & 180 & $9.1^{\mathrm{f}}$ & $12.8^{\mathrm{d}}$ & $5.6^{\mathrm{f}}$ & $89^{g}(-31)$ \\
\hline \multirow[t]{4}{*}{ Gharehyonje } & 0 & $8.7^{\mathrm{h}}$ & $12.4^{\mathrm{d}}$ & $8.3^{\mathrm{c}}$ & $119^{\mathrm{d}}$ \\
\hline & 60 & $8.2^{\mathrm{jk}}$ & $11.3^{\mathrm{e}}$ & $7.2^{\mathrm{d}}$ & $109^{\mathrm{e}}(-8)$ \\
\hline & 120 & $7.7^{\mathrm{m}}$ & $10^{\mathrm{f}}$ & $6.3^{\mathrm{e}}$ & $99^{f}(-16)$ \\
\hline & 180 & $7.2^{\circ}$ & $9.3^{\mathrm{g}}$ & $5.5^{\mathrm{f}}$ & $79^{\mathrm{h}}(-33)$ \\
\hline \multirow[t]{4}{*}{ Ranjer } & 0 & $8.3^{\mathrm{j}}$ & $11^{\mathrm{e}}$ & $8.2^{\mathrm{c}}$ & $99^{\mathrm{f}}$ \\
\hline & 60 & $8^{1}$ & $10.4^{\mathrm{f}}$ & $6.6^{\mathrm{e}}$ & $79^{\mathrm{h}}(-20)$ \\
\hline & 120 & $7.5^{\mathrm{n}}$ & $9.9^{f}$ & $5.6^{\mathrm{f}}$ & $59^{\mathrm{i}}(-40)$ \\
\hline & 180 & $6.8^{\mathrm{q}}$ & $8.9^{\mathrm{g}}$ & $4.8^{\mathrm{h}}$ & $29^{\mathrm{m}}(-70)$ \\
\hline \multirow[t]{4}{*}{ Hamedani } & 0 & $6.5^{\mathrm{r}}$ & $8.4^{\mathrm{h}}$ & $5.8^{\mathrm{f}}$ & $79^{\mathrm{h}}$ \\
\hline & 60 & $6.2^{\mathrm{s}}$ & $8.1^{\mathrm{h}}$ & $5.0^{\mathrm{gh}}$ & $69^{\mathrm{i}}(-12)$ \\
\hline & 120 & $5.5^{\mathrm{u}}$ & $7.1^{\mathrm{i}}$ & $4.1^{\mathrm{i}}$ & $59^{\mathrm{j}}(-25)$ \\
\hline & 180 & $4^{\mathrm{x}}$ & $6^{\mathrm{j}}$ & $3.3^{\mathrm{k}}$ & $39^{1}(-50)$ \\
\hline \multirow[t]{4}{*}{ Yazdi } & 0 & $7^{\mathrm{p}}$ & $9.1^{\mathrm{g}}$ & $5.4^{\mathrm{fg}}$ & $59^{j}$ \\
\hline & 60 & $6.2^{\mathrm{s}}$ & $8.3^{\mathrm{h}}$ & $4.7^{\mathrm{h}}$ & $49^{k}(-16)$ \\
\hline & 120 & $5^{\mathrm{v}}$ & $7^{i}$ & $3.8^{\mathrm{ij}}$ & $39^{1}(-33)$ \\
\hline & 180 & $4.5^{\mathrm{w}}$ & $6^{\mathrm{j}}$ & $2.9^{\mathrm{kl}}$ & $19^{\mathrm{n}}(-67)$ \\
\hline \multirow[t]{4}{*}{ Nikshahri } & 0 & $6.9^{\mathrm{pq}}$ & $9^{\mathrm{g}}$ & $3.1^{\mathrm{k}}$ & $39^{1}$ \\
\hline & 60 & $6^{t}$ & $7.9^{\mathrm{h}}$ & $2.4^{\mathrm{m}}$ & $29^{\mathrm{m}}(-25)$ \\
\hline & 120 & $4.5^{\mathrm{w}}$ & $6.1^{\mathrm{j}}$ & $1.9^{\mathrm{mno}}$ & $21^{\mathrm{n}}(-46)$ \\
\hline & 180 & $4^{\mathrm{x}}$ & $5^{\mathrm{k}}$ & $1.6^{\text {nop }}$ & $9^{\text {op }}(-76)$ \\
\hline \multirow[t]{4}{*}{ Pioneer } & 0 & $5^{\mathrm{v}}$ & $5.8^{\mathrm{j}}$ & $2.0^{\mathrm{mn}}$ & $19^{\mathrm{n}}$ \\
\hline & 60 & $4^{\mathrm{x}}$ & $4.7^{\mathrm{k}}$ & $1.4^{\mathrm{op}}$ & $11^{\circ}(-42)$ \\
\hline & 120 & $3.4^{y}$ & $4^{1}$ & $0.9^{\mathrm{pq}}$ & $8^{\mathrm{op}}(-57)$ \\
\hline & 180 & $2.5^{\mathrm{z}}$ & $3^{\mathrm{m}}$ & $0.4^{\mathrm{rs}}$ & $4^{\mathrm{p}}(-78)$ \\
\hline \multirow[t]{4}{*}{ Bami } & 0 & $5.6^{\mathrm{u}}$ & $7.2^{\mathrm{i}}$ & $1.6^{\mathrm{nop}}$ & $9^{\text {op }}$ \\
\hline & 60 & $4.5^{\mathrm{w}}$ & $6.8^{\mathrm{j}}$ & $0.9^{\mathrm{pq}}$ & $8^{\mathrm{op}}(-11)$ \\
\hline & 120 & $4^{\mathrm{x}}$ & $5.7^{\mathrm{j}}$ & $0.8^{\mathrm{qr}}$ & $5^{\mathrm{p}}(-44)$ \\
\hline & 180 & $3.4^{y}$ & $4.9^{\mathrm{k}}$ & $0.3^{\mathrm{s}}$ & $4^{\mathrm{kl}}(-55)$ \\
\hline LSD & & 1.71 & 0.6 & 0.5 & 5 \\
\hline
\end{tabular}

${ }^{\dagger}$ Mean within columns with the same letters is not significantly different at $5 \%$ level. 
Table 2. Effect of salinity on activities of enzymes and lipid peroxidation of alfalfa cultivars.

\begin{tabular}{|c|c|c|c|c|c|c|}
\hline \multirow{3}{*}{ Cultivar } & \multirow{3}{*}{$\mathrm{NaCl}(\mathrm{mM})$} & \multicolumn{4}{|c|}{ Activities of enzymes } & \multirow{3}{*}{$\frac{\text { MDA content }}{\mathrm{nmol} \mathrm{g} / \mathrm{FW}}$} \\
\hline & & SOD & POX & APOX & GR & \\
\hline & & \multicolumn{4}{|c|}{ unit mg/protein } & \\
\hline \multirow[t]{4}{*}{ Rehnani } & 0 & $39^{\mathrm{uv} \dagger}$ & $3.7^{\text {gghi }}$ & $1.9^{\operatorname{lmn} \dagger}$ & $0.56^{\operatorname{lmn} \dagger}$ & $6.2^{\mathrm{v \dagger}}$ \\
\hline & 60 & $59^{\mathrm{qr}}$ & $4.5^{\mathrm{ef}}$ & $2.8^{\mathrm{gh}}$ & $0.7^{\mathrm{hijk}}$ & $6.4^{\mathrm{uv}}$ \\
\hline & 120 & $119^{\mathrm{e}}$ & $6.9^{\mathrm{cd}}$ & $4.3^{\mathrm{e}}$ & $1.08^{\mathrm{de}}$ & $6.7^{\text {tuv }}$ \\
\hline & 180 & $179^{\mathrm{a}}$ & $8.7^{\mathrm{ab}}$ & $6.5^{\mathrm{bc}}$ & $1.33^{\mathrm{b}}$ & $6.9^{\mathrm{tu}}$ \\
\hline \multirow[t]{4}{*}{ Esfahani } & 0 & $55^{\mathrm{r}}$ & $4.2^{\mathrm{fg}}$ & $2.6^{\mathrm{hijk}}$ & $0.57^{\mathrm{klmn}}$ & $6.6^{\text {tuv }}$ \\
\hline & 60 & $72^{\mathrm{kl}}$ & $4.9^{\mathrm{ef}}$ & $3.9^{\text {ef }}$ & $0.82^{\text {gh }}$ & $6.8^{\mathrm{tuv}}$ \\
\hline & 120 & $109^{\mathrm{fg}}$ & $5.7^{\mathrm{de}}$ & $5.7^{\mathrm{c}}$ & $1.19^{\mathrm{cd}}$ & $6.9^{\text {tu }}$ \\
\hline & 180 & $164^{\mathrm{b}}$ & $6.8^{\mathrm{cd}}$ & $7.8^{\mathrm{a}}$ & $1.48^{\mathrm{a}}$ & $7.2^{\mathrm{t}}$ \\
\hline \multirow[t]{4}{*}{ Gharehyonje } & 0 & $49^{\mathrm{st}}$ & $4.8^{\mathrm{ef}}$ & $1.7^{\mathrm{mno}}$ & $0.48^{\text {nop }}$ & $7.9^{\mathrm{s}}$ \\
\hline & 60 & $72^{\mathrm{mn}}$ & $5.7^{\mathrm{de}}$ & $2.8^{\mathrm{hij}}$ & $0.67^{\mathrm{ijkl}}$ & $8.6^{\mathrm{r}}$ \\
\hline & 120 & $99^{\mathrm{h}}$ & $6.9^{\mathrm{cd}}$ & $3.9^{\text {ef }}$ & $0.98^{\mathrm{ef}}$ & $9.4^{\mathrm{q}}$ \\
\hline & 180 & $154^{\mathrm{c}}$ & $7.7^{\mathrm{bc}}$ & $5.8^{\mathrm{c}}$ & $1.22^{\mathrm{bc}}$ & $10.1^{\mathrm{p}}$ \\
\hline \multirow[t]{4}{*}{ Ranjer } & 0 & $84^{\mathrm{kj}}$ & $1.9^{\mathrm{kl}}$ & $2.3^{\mathrm{ijkl}}$ & $0.35^{\mathrm{qrst}}$ & $10.9^{\circ}$ \\
\hline & 60 & $92^{\mathrm{i}}$ & $4.7^{\mathrm{ef}}$ & $3.6^{\mathrm{f}}$ & $0.53^{\mathrm{mno}}$ & $11.8^{\mathrm{mn}}$ \\
\hline & 120 & $112^{\mathrm{f}}$ & $7.6^{\mathrm{bc}}$ & $5.1^{\mathrm{d}}$ & $0.68^{\mathrm{ijk} l}$ & $12.7^{\mathrm{kl}}$ \\
\hline & 180 & $129^{\mathrm{d}}$ & $9.2^{\mathrm{a}}$ & $6.9^{\mathrm{b}}$ & $0.89^{\mathrm{fg}}$ & $13.4^{\mathrm{hij}}$ \\
\hline \multirow[t]{4}{*}{ Hamedani } & 0 & $79^{\mathrm{kl}}$ & $2.8^{\mathrm{hijk}}$ & $1.4^{\text {nop }}$ & $0.41^{\text {opqr }}$ & $11.3^{\mathrm{no}}$ \\
\hline & 60 & $89^{\mathrm{ij}}$ & $5.2^{\mathrm{ef}}$ & $2.2^{\mathrm{jkl}}$ & $0.58^{\mathrm{klmn}}$ & $12.1^{\mathrm{lm}}$ \\
\hline & 120 & $104^{\mathrm{gh}}$ & $7.7^{\mathrm{bc}}$ & $3.4^{\mathrm{fg}}$ & $0.76^{\mathrm{ghi}}$ & $13^{\mathrm{ijk}}$ \\
\hline & 180 & $119^{\mathrm{e}}$ & $9.6^{\mathrm{a}}$ & $4.9^{\mathrm{d}}$ & $0.98^{\mathrm{ef}}$ & $13.9^{\mathrm{gh}}$ \\
\hline \multirow[t]{4}{*}{ Yazdi } & 0 & $59^{\mathrm{qr}}$ & $1.2^{1}$ & $0.77^{\mathrm{qr}}$ & $0.24^{\text {tu }}$ & $12.8^{\mathrm{jk}}$ \\
\hline & 60 & $66^{\mathrm{op}}$ & $1.7^{\mathrm{kl}}$ & $1.3^{\mathrm{op}}$ & $0.33^{\mathrm{rst}}$ & $13.7^{\mathrm{h}}$ \\
\hline & 120 & $84^{\mathrm{jk}}$ & $2.4^{\mathrm{ijkl}}$ & $2.7^{\mathrm{ij}}$ & $0.57^{\mathrm{lmn}}$ & $14.6^{\mathrm{ef}}$ \\
\hline & 180 & $99^{\mathrm{h}}$ & $3.8^{\text {fghi }}$ & $3.9^{\text {ef }}$ & $0.73^{\text {hij }}$ & $15.4^{\mathrm{cd}}$ \\
\hline \multirow[t]{4}{*}{ Nikshahri } & 0 & $54^{\mathrm{rs}}$ & $1.5^{\mathrm{kl}}$ & $0.97^{\mathrm{pqr}}$ & $0.18^{\mathrm{uvw}}$ & $13.6^{\mathrm{hi}}$ \\
\hline & 60 & $63^{\mathrm{pq}}$ & $2.1^{\mathrm{jkl}}$ & $1.1^{\mathrm{opq}}$ & $0.29^{\text {stu }}$ & $14.4^{\mathrm{fg}}$ \\
\hline & 120 & $75^{\mathrm{lm}}$ & $3.2^{\text {ghij }}$ & $3^{\mathrm{gh}}$ & $0.48^{\text {nop }}$ & $15^{\mathrm{def}}$ \\
\hline & 180 & $89^{\mathrm{ij}}$ & $4.7^{\mathrm{ef}}$ & $4.2^{\mathrm{e}}$ & $0.62^{\mathrm{jklm}}$ & $16.2^{\mathrm{b}}$ \\
\hline \multirow[t]{4}{*}{ Pioneer } & 0 & $36^{\mathrm{v}}$ & $2.7^{\mathrm{hijk}}$ & $0.47^{\mathrm{r}}$ & $0.08^{\mathrm{w}}$ & $13.6^{\mathrm{hi}}$ \\
\hline & 60 & $44^{\text {tu }}$ & $3.2^{\text {ghij }}$ & $0.98^{\mathrm{pqr}}$ & $0.19^{\mathrm{uvw}}$ & $14.4^{\mathrm{fg}}$ \\
\hline & 120 & $54^{\mathrm{rs}}$ & $3.9^{\mathrm{fgh}}$ & $2.1^{\mathrm{klm}}$ & $0.37^{\mathrm{pqrs}}$ & $15.2^{\mathrm{de}}$ \\
\hline & 180 & $77^{\operatorname{lm}}$ & $5.7^{\mathrm{de}}$ & $3.4^{\mathrm{fg}}$ & $0.48^{\text {nop }}$ & $16^{\mathrm{bc}}$ \\
\hline \multirow[t]{4}{*}{ Bami } & 0 & $29^{w}$ & $4^{\mathrm{fgh}}$ & $0.37^{\mathrm{r}}$ & $0.11^{\mathrm{vw}}$ & $14.4^{\mathrm{fg}}$ \\
\hline & 60 & $34^{\mathrm{vw}}$ & $4.7^{\mathrm{ef}}$ & $0.67^{q \mathrm{r}}$ & $0.23^{\text {tuv }}$ & $15.2^{\mathrm{de}}$ \\
\hline & 120 & $49^{\mathrm{st}}$ & $5.8^{\mathrm{de}}$ & $1.4^{\mathrm{nop}}$ & $0.46^{\text {nopq }}$ & $16^{\mathrm{bc}}$ \\
\hline & 180 & $69^{\text {no }}$ & $6.7^{\mathrm{c}}$ & $2.8^{\mathrm{gi}}$ & $0.58^{\mathrm{klmn}}$ & $16.9^{\mathrm{a}}$ \\
\hline LSD & & 5.7 & 1.4 & 0.59 & 0.12 & 0.6 \\
\hline
\end{tabular}

${ }^{\dagger}$ Mean within columns with the same letters is not significantly different at $5 \%$ level. 
Salinity increase of GR activity by 4.33 -folds in Pioneer. followed by $3.85-1.86$-folds in Bami, Nikshahre, Yazdi, Esfahani, Ranjer, Gharehyonje, Hamedani, and Rehnani (Table 2). GR activity was higher in salt tolerant cotton cultivars (Meloni et al. 2003). However, the enhancement of APX activity was greater in salt tolerant than in salt sensitive alfalfa cultivars (Wang et al. 2009; Babakhani et al. 2011). The positive relation between APX and salt tolerance has also been reported in wild beet (Bor et al. 2003). The $\mathrm{H}_{2} \mathrm{O}_{2}$ produced by SOD may also be detoxified in the ascorbate-glutathione pathway (Wang et al. 2009), which involves the oxidation of ascorbate by APX and reduction of glutathione by GR (Wang et al. 2009). On the other hand, the increase in APX and GR activities appears to be an indication of salt tolerance in tested alfalfa cultivars. APX is a component of the ascorbate-glutathione pathway, which plays a key role in scavenging $\mathrm{H}_{2} \mathrm{O}_{2}$ (Wang and Han 2009). The activities of APX and GR were higher in salt tolerance cultivars as compared to sensitive cultivars suggesting that these enzymes may play an important role in salt tolerant mechanisms in alfalfa.

MDA content which is an indicator of lipid peroxidation of alfalfa seedlings was significantly enhanced under saline treatments (Table 2). The average increase in MDA content under saline treatments increase from $5.55-18.6 \%$ in Esfahani, Rehnani, Bami, Pioneer, Yazdi, Nikshahre, Hamedani, Ranjer, and Gharehyonje (Table 2). Similar results were observed in salt tolerant and salt sensitive cultivars of alfalfa (Wang et al. 2009, Wang and Han 2009, Babakhani et al. 2011) and barley (Liang et al. 2003). Lipid peroxidation is an identified cell membrane damage mechanism, and is used as an indication of oxidative stress caused by various stresses including salt stress (Babakhani et al. 2011). The result suggested that ROX was increased under salt stress, however, increased in antioxidant enzymes activities suppressed the damages caused by ROX in tolerant cultivars.

Changes in seeds and seedlings growth parameters of the cultivars under salt stress showed that Rehnani and Esfahani were most salt tolerant while Bami and Pioneer were the most salt sensitive cultivars. The activities of SOD, GR, POX and APOX were higher in salt tolerant and lower in salt sensitive cultivars. The MDA content was lower in salt tolerance cultivars as compared to sensitive cultivars. These results showed that the SOD, GR, POX, APOX activities and MDA content at the germination and seedling stages may be used to select salt tolerance cultivars.

\section{References}

Babakhani B, Khavari-Nejad RA, Hassan Sajedi R, Fahimi H and Saadatmand S 2011. Biochemical responses of Alfalfa (Medicago sativa L.) cultivars subjected to $\mathrm{NaCl}$ salinity stress. African J. Biotechnol. 10: 11433-11441.

Beauchamp CO and Fridovich I 1971. Superoxide dismutase: improved assays and an assay applicable to acrylamide gels. Ann. Biochem. 44: 276-287.

Bor M, Ozdemir F and Turkan I 2003. The effect of salt stress on lipid peroxidation and antioxidants in leaves of sugar beet Beta vulgaris L. and wild beet Beta maritima L. Plant Sci. 164: 77-84.

Foyer CH and Halliwell B 1976. The presence of glutathione and glutathione reductase in chloroplasts: a proposed role in ascorbic acid metabolism. Plantarum 133: 21-25.

Herzog V and Fahimi H 1973. Determination of the activity of peroxidase. Ann. Biochem. 55: 554-562.

Howieson J and Ballard R 2004. Optimising the legume symbiosis in stressful and competitive environments within southern Australia: some contemporary thoughts. Soil Biol. Biochem. 36: 1261-1273.

Jaleel CA, Lakshmanan GMA, Gomathinayagam M and Panneerselvam R 2008. Triadimefon induced salt stress tolerance in Withania somnifera and its relationship to antioxidant defense system. South African J. Botany 74: 126-132. 
Liang Y, Chen Q, Liu Q, Zhang W and Ding R 2003. Exogenous silicon (Si) increases antioxidant enzyme activity and reduces lipid peroxidation in roots of salt-stressed barley (Hordeum vulgare L.). J. Plant Physiol. 160: 1157-1164.

Madhava KV and Sresty TVS 2000. Antioxidative parameters in the seedlings of pigeonpea (Cajanus cajan (L.) Millspaugh) in response to $\mathrm{Zn}$ and Ni stresses. Plant Sci. 157: 113-128.

Meloni DA, Oliva MA, Martinez CA and Cambraia J 2003. Photosynthesis and activity of superoxide dismutase, peroxidase and glutathione reductase in cotton under salt stress. Environ. Exp. Bot. 49: 69-76.

Nakano Y and Asada K 1981. Hydrogen peroxide is scavenged by ascorbate specific peroxidase in spinach chloroplasts. Plant Cell Physiol. 22: 867-880.

Peel MD, Waldron BL, Jensen KB, Chatterton NJ, Horton H and Dudley LM 2004. Screening for Salinity Tolerance in Alfalfa: A Repeatable Method. Crop Sci. 44: 2049-2053.

SAS Institute Inc 2007. SAS OnlineDoc 9.1.3. Cary, NC: SAS Institute Inc.

Sudhakar C, Lakshmi A and Giridarakumar S 2001. Changes in the antioxidant enzymes efficacy in two high yielding genotypes of mulberry (Morus alba L.) under NaCl salinity. Plant Sci. 161: 613-619.

Torabi M, Halim RA, Sinniah UR and Choukan R 2011. Influence of salinity on the germination of Iranian alfalfa ecotypes. African J. Agric. Res. 6: 4624-4630.

Wang F, Chu R, Yang J, Gong Y and Zhu X 2009. Cadmium accumulation and antioxidant enzyme activity in response to cadmium stress in radish (Raphanus sativus L.). pp. 1-4. Proc. $3^{\text {rd }}$ Int. Conf. Bioinformatics and Biomedical Engineering, June 11-13, 2009. Beijing, China.

Wang XS and Han JG 2009. Changes of proline content, activity, and active isoforms of antioxidative enzymes in two alfalfa cultivars under salt stress. Agric. Science China 8: 431-440.

(Manuscript received on 25 September, 2013; revised on 26 February, 2014) 